\title{
Attempts to improve the self-cleaning effect of the textile materials
}

\author{
DOI: 10.35530/IT.071.03.1626
}

IULIANA DUMITRESCU

LUCIA OANA SECĂREANU

OVIDIU-GEORGE IORDACHE

LAURENTIIU CHRISTIAN DINCĂ

CORNELIA-ELENA MITRAN

ARCADII SOBETKII

ELENA PERDUM

IRINA-MARIANA SĂNDULACHE

LUCIAN DIAMANDESCU

ABSTRACT - REZUMAT

\section{Attempts to improve the self-cleaning effect of the textile materials}

The objective of this study is to investigate the methods to create durable self-cleaning textiles by coating fabrics with $\mathrm{TiO}_{2}-(1 \%) \mathrm{Fe}-\mathrm{N}$-graphene (2\%). To improve the adherence of the nanoparticles, the polyester/cotton woven fabrics were pre-treated with polyacrylic acid (PA), carboxymethylcellulose (CMC) and polyethylene polyamine resin (EZF). The pre-treated materials were immersed in a doped $\mathrm{TiO}_{2}$ for 30 minutes at $40^{\circ} \mathrm{C}$ and dried at $125^{\circ} \mathrm{C}$. The finished fabrics were stained with methylene blue dye and exposed to visible light.

The SEM images show the presence of particles on polymers layers firmly attached on the material surface. The treatments determine the decrease of the exothermic peak $\left(452.48^{\circ} \mathrm{C}\right)$, characteristic of the cellulose decomposition, demonstrating an increase of the thermal conductivity of the materials. The doped $\mathrm{TiO}_{2}$-graphene induces a double degradation of methylene blue in comparison with untreated material and the materials treated with CMC, polyacrylic acid and cationic polymer. The effect is maintained after washing.

Keywords: doped $\mathrm{TiO}_{2}$-graphene, photocatalytic textiles, self-cleaning

\section{Încercări de îmbunătățire a efectului de auto-curățare al materialelor textile}

Obiectivul acestui studiu îl reprezintă cercetarea metodei de obținere a materialelor textile cu proprietăți de auto-curățare, durabile, prin acoperirea $\mathrm{cu} \mathrm{TiO}_{2}-(1 \%) \mathrm{Fe}-\mathrm{N}$-grafen (2\%). Pentru a îmbunătăți aderența nanoparticulelor, țesăturile din poliester/bumbac au fost pre-tratate cu acid poliacrilic (PA), carboximetilceluloză (CMC) și rășină polietilen poliamilică (EZF). Materialele textile pre-tratate au fost imersate în $\mathrm{TiO}_{2}$ dopat, timp de 30 de minute la $40^{\circ} \mathrm{C}$ și uscate la $125^{\circ} \mathrm{C}$. Țesăturile finisate au fost pătate cu albastru de metilen și expuse la lumină vizibilă.

Analiza SEM evidențiază prezența particulelor pe straturile polimerice, bine fixate pe suprafața materialului. Tratamentele determină scăderea vârfului exotermic $\left(452,48^{\circ} \mathrm{C}\right)$, caracteristic descompunerii celulozei, demonstrând o creștere a conductivității termice a materialului. $\mathrm{TiO}_{2}$-grafen dopat induce o dublă degradare a albastrului de metilen în comparație cu materialul netratat și materialele tratate cu CMC, acid poliacrilic și polimer cationic. Efectul se menține și după spălare.

Cuvinte-cheie: $\mathrm{TiO}_{2}$-grafen dopat, textile fotocatalitice, auto-curățare

\section{INTRODUCTION}

Self-cleaning textiles have many applications for protective uniforms, upholstery and carpets, window blinds, tents and awnings, filter fabrics, agricultural textiles, etc. [1]. Different compounds were tested to improve the photocatalytic self-cleaning efficiency such as $\mathrm{TiO}_{2}$ doped with metals, non-metals, metalsno-metals co-doping, dyes, heterojunctions $\left(\mathrm{ZnO} / \mathrm{TiO}_{2}\right.$; $\mathrm{TiO}_{2} / \mathrm{SiO}_{2} ; \mathrm{TiO}_{2} / \mathrm{WO}_{3}$ ). Recently, doped $\mathrm{TiO}_{2}$-graphene nanocomposites are intensive investigated due their efficiency to decompose pollutants and pathogenic microorganisms under visible light [2-6]. It is largely accepted that the high interfacial contact between graphene sheet and $\mathrm{TiO}_{2}$ nanoparticles facilitates the charge separation and electron transfer from $\mathrm{TiO}_{2}$ to graphene upon irradiation and overcome the fast recombination of the electrons and holes pairs, improving the photocatalytic activity [7].
Different physical and chemical methods were proposed for the immobilization of graphene- $\mathrm{TiO}_{2}$ on textiles such as atmospheric pressure metal organic chemical vapor deposition, electron beam evaporation, reactive magnetron sputtering, spray pyrolysis, sol-gel, and layer by layer assembly technique [8]. The most used method to prepare self-cleaning textiles remains the dip-pad-dry-cure method [9-11] due its large applicability on conventional production lines. The major drawback of immobilized $\mathrm{TiO}_{2}$ composites is the low coating adherence.

The objectives of this study are to investigate the methods to create durable self-cleaning textiles by coating fabrics with $\mathrm{TiO}_{2}-(1 \%) \mathrm{Fe}-\mathrm{N}$-graphene $(2 \%)$. To improve the adherence of the nanoparticles, the polyester/cotton woven fabrics were pre-treated with polyacrylic acid (PA), carboxymethylcellulose (CMC) and polyethylene polyamine resin (EZF). 


\section{EXPERIMENTAL}

\section{Materials}

Scoured and bleached 33\% cotton $/ 67 \%$ polyester woven fabric, $\mathrm{TiO}_{2}-(1 \%) \mathrm{Fe}-\mathrm{N}$-graphene (2\%), polyacrylic acid $(\mathrm{Mwt}=138.1 \mathrm{~g} / \mathrm{mol})$, carboxymethylcellulose $(C M C)$ and polyethylene polyamine resin (ITOFIX EZF, Fast Colours, UK), sodium dodecylhydrogenesulfate (DHS, Merck), Tween 80 (Sigma Aldrich), ethanol, a-terpineol (Merk), Imerol JSF (Archroma).

\section{Methods}

Preparation of $0.7 \mathrm{~g} / \mathrm{l} \mathrm{TiO}_{2}-(1 \%) \mathrm{Fe}-\mathrm{N}$-graphene (2\%) dispersion

To prepare the dispersion, in a 2 l reactor were successively added under intensive stirring on ultrasonic bath the following compounds: $527 \mathrm{ml}$ of water, $351 \mathrm{ml}$ of ethanol, $88 \mathrm{ml}$ of terpineol, $4.5 \mathrm{ml}$ of EHS, $17.5 \mathrm{ml}$ of Tween $80,10.5 \mathrm{ml}$ of Imerol JSF, $0.8 \mathrm{~g}$ DHS and $0.7 \mathrm{~g}$ doped $\mathrm{TiO}_{2}$-graphene. The mixture was stirred at $40^{\circ} \mathrm{C}$ for $60 \mathrm{~min}$. A white-gray dispersion is formed.

Fabric treatment

Cotton/polyester fabrics were separately immersed in $1 \mathrm{~g} / \mathrm{l}$ carboxymethylcellulose (CMC), $1 \mathrm{~g} / \mathrm{l}$ polyacrylic acid (PA) and $10 \mathrm{~g} / \mathrm{l}$ Itofix EZF solutions, kept at $80^{\circ} \mathrm{C}$ for 20 minutes and then, dried at $120^{\circ} \mathrm{C}$. The pretreated, dried materials are immersed in $0.7 \mathrm{~g} / \mathrm{l} \mathrm{TiO}{ }_{2}-$ (1\%) Fe-N-graphene (2\%) dispersion, maintained under stirring at $40^{\circ} \mathrm{C}$ for 30 minutes and dried in the preheated oven at $125^{\circ} \mathrm{C}$.

Material abbreviation is the following:

A: cotton/polyester fabric immersed in $\mathrm{TiO}_{2}$-graphene dispersion;

CMC: cotton/polyester fabric immersed in $1 \mathrm{~g} / \mathrm{l} \mathrm{CMC;}$ $\mathrm{B}$ : cotton/polyester fabric immersed in $1 \mathrm{~g} / \mathrm{l} \mathrm{CMC}$ and later in $\mathrm{TiO}_{2}$-graphene dispersion;

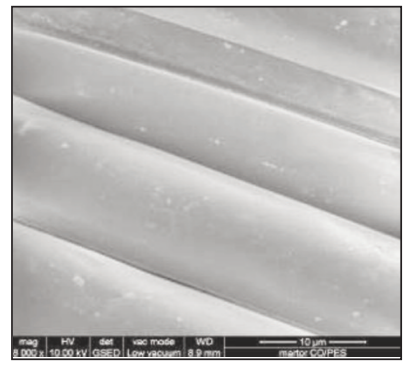

Untreated material

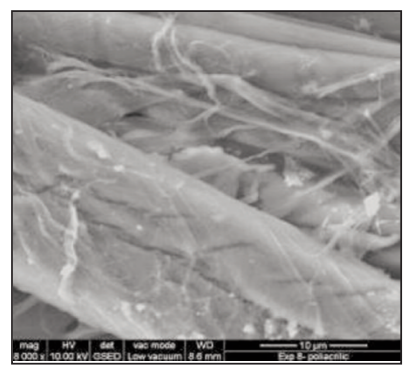

PA

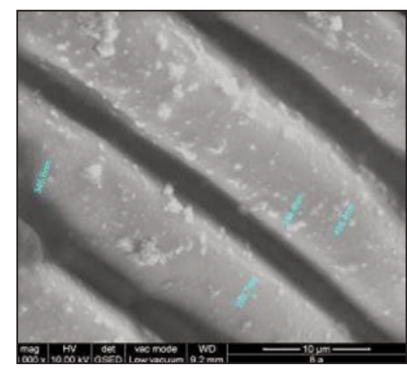

A

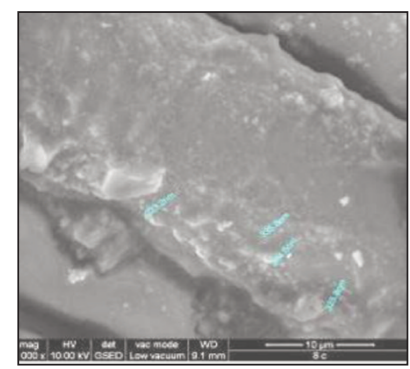

C

PA: cotton/polyester fabric immersed in $1 \mathrm{~g} / \mathrm{l}$ polyacrylic acid;

C: cotton/polyester fabric immersed in $1 \mathrm{~g} / \mathrm{l}$ polyacrylic acid and subsequently in $\mathrm{TiO}_{2}$-graphene dispersion;

EZF: cotton/polyester fabric immersed in $10 \mathrm{~g} / \mathrm{l}$ Itofix $\mathrm{EZF}$;

D: cotton/polyester fabric immersed in Itofix EZF and later in $\mathrm{TiO}_{2}$-graphene dispersion.

\section{Characterization}

The morphology of the fabric was investigated by scanning electron microscope (SEM, Quanta 200, FEI, Holland). The wetting ability was determined by measuring the contact angles of $5 \mu$ l distilled water droplet on a VCA Optima (AST Products Inc., USA) instrument. The results are the average of 5-10 measurements in different points on the samples surface. The thermal properties of the coated fabric were measured on DSC (Pyris Diamond, Perkin Elmer, USA) instrument, with a heating rate of $10^{\circ} \mathrm{C} /$ minute and using $10 \mathrm{ml} /$ minute air as a purging gas. The electrical resistivity was measured with PRS 801 digital multi-meter (Prostat Corporation, USA), according standard SR EN $1149-1: 2006$, at $20.7^{\circ} \mathrm{C}$ and $28.8 \%$ relative humidity. The photocatalytic efficiency of the untreated and treated materials was evaluated initially and after 5 washing cycles, by measuring the trichromatic coordinates of materials stained with methylene blue and exposed at UV and visible light on Hunterlab spectrophotometer, with CIELAB 1976 color space and D65-light source.

\section{RESULTS AND DISSCUSION}

\section{Characterization of the fabric by Scanning Electron Microscopy (SEM)}

The spreading of the particles and their size on the surfaces of the treated fabrics are shown on the SEM images (figure 1).

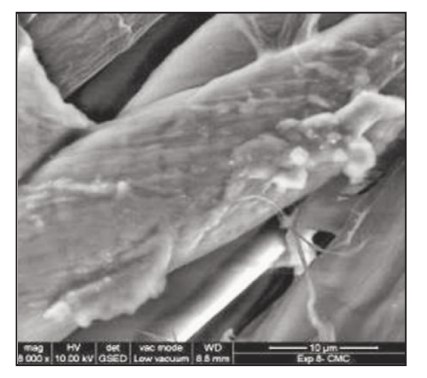

CMC

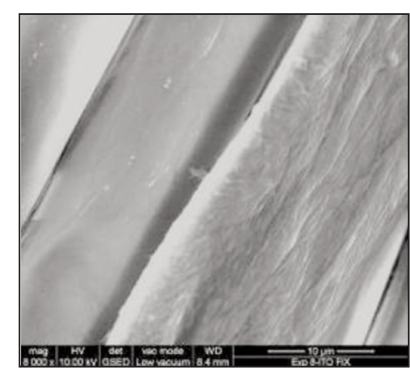

$E Z F$

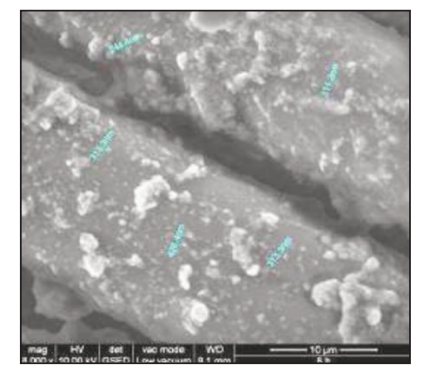

B

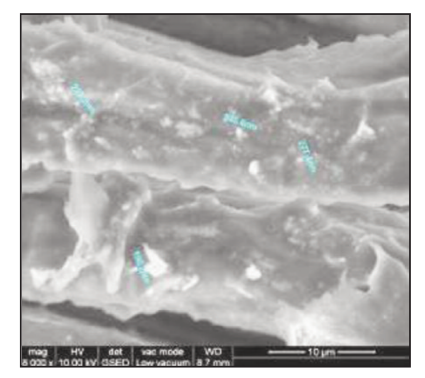

D

Fig. 1. SEM images of untreated and treated fabrics 


\begin{tabular}{|c|c|c|c|c|c|c|c|c|}
\hline \multicolumn{9}{|c|}{ IMAGES OF WATER DROPLETS AND CONTACT ANGLE VALUES } \\
\hline Sample & \multicolumn{2}{|c|}{ Untreated fabric } & \multicolumn{2}{|c|}{ CMC } & \multicolumn{2}{|c|}{ PA } & \multicolumn{2}{|c|}{ EZF } \\
\hline $\begin{array}{c}\text { Contact angle } \\
\text { left/right }\left(^{\circ}\right)\end{array}$ & 133.22 & 133.45 & 137.02 & 136.22 & 129.02 & 130.37 & 134.92 & 135.32 \\
\hline Image & & & & & & & & \\
\hline
\end{tabular}

SEM images show the $\mathrm{TiO}_{2}$ particles on cotton/ polyester woven fabric samples, before and after treatments. The samples CMC, PA, EZF are covered with thick layers of polymers. After the immersion in the doped- $\mathrm{TiO}_{2}-$ graphene dispersion, a large number of particles cover the fibers surface. The particles are in a larger number and more uniformly spread on the surface of the fabric coated only with doped $-\mathrm{TiO}_{2}$-graphene $(\mathrm{A})$ than on the surface of the samples covered with polymers and $\mathrm{TiO}_{2}$-graphene

\begin{tabular}{|c|c|c|c|}
\hline \multicolumn{4}{|c|}{ MATERIALS ELECTRICAL RESISTIVITY } \\
\hline Sample & $\begin{array}{c}\text { Surface resistivity } \\
\left(\Omega \mathbf{s q} \times \mathbf{1 0}^{\mathbf{1 3}}\right)\end{array}$ & $\begin{array}{c}\text { Volume resistivity } \\
\left(\Omega \times \mathbf{c m} \times \mathbf{1 0}^{\mathbf{1 5}}\right)\end{array}$ & $\begin{array}{c}\text { Thickness } \\
(\mathbf{m m})\end{array}$ \\
\hline Untreated material & 29.5 & 2.67 & 0.40 \\
\hline A & 42.5 & 11.2 & 0.41 \\
\hline CMC & 15.5 & 9.09 & 0.44 \\
\hline B & 63 & 2.48 & 0.43 \\
\hline PA & 15.5 & 8.82 & 0.43 \\
\hline C & 25 & 43.3 & 0.43 \\
\hline EZF & 20.5 & 10.5 & 0.44 \\
\hline D & 35 & 4.33 & 0.43 \\
\hline
\end{tabular}
$(B, C, D)$. As it can be seen from images, the particles are more agglomerated on the fabric $B$, covered initially with $\mathrm{CMC}$, probably due to porous surface of CMC and carboxyl groups which attract $\mathrm{TiO}_{2}$ particles.

\section{Surface wettability of the treated fabrics}

Due to the high content of thin polyester yarns and tight structure of the fabric, the untreated woven material is highly hydrophobic (contact angle of $133^{\circ}$ ). The hydrophoby of the materials is not significantly changed (table 1 ) if the materials are covered with polymers. After the $\mathrm{TiO}_{2}$-graphene treatment, the water static contact angle becomes zero, the water droplet being absorbed in less than 60 seconds, indicating a completely water wettability of the fabrics. The increased hydrophilic behavior of the materials could be correlated with the deposition of a large number of $\mathrm{TiO}_{2}$ particles on the materials surface knowing that graphene has water and oil repellency properties [12].

\section{Evaluation of the electrical resistivity}

The results of the materials' electrical resistivity are shown in the table 2 .

Cotton/polyester fabric has anionic properties due to the hydroxyl and carboxyl groups respectively. By depositing layers of carboxymethylcellulose (sample $\mathrm{CMC}$ ) and polyacrylic acid (sample PA), the anionic character is accentuated leading to the decrease of the surface electrical resistivity. A smaller decrease of the electrostatic was observed for the fabric EZF covered with polyethylene polyamine layers. The materials coated with polymers and $\mathrm{TiO}_{2}$-graphene show higher electrical resistivities due to the thick layers and large agglomerates formed on the cotton/ polyester surface [13].

\section{Thermal conductivity}

The thermal behavior of the coated samples is shown in the figure 2 and tables 3 and 4 .

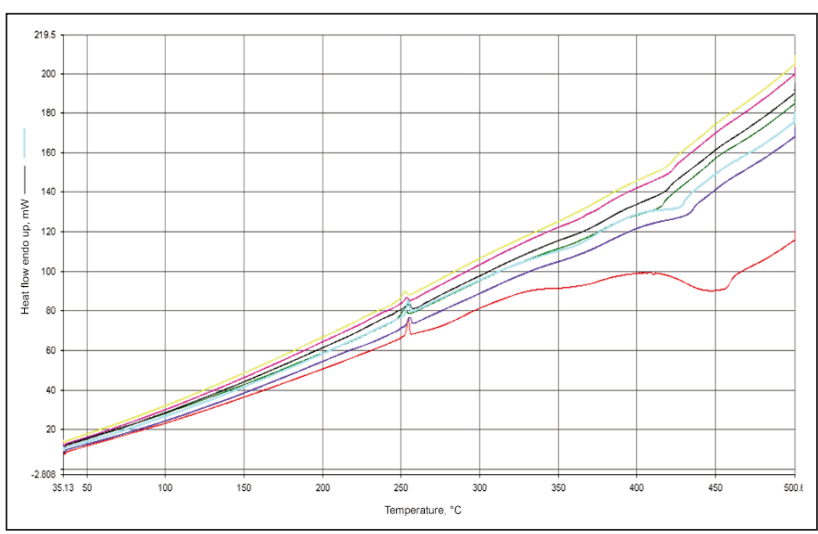

Fig. 2. DSC thermograme: $D$ - yellow; $C$ - purple; $\mathrm{B}$ - black; A - green; PA - blue; EZF - blue marine; $\mathrm{CMC}$ - red

The untreated material has 3 peaks, the first endotherm $\left(254.45^{\circ} \mathrm{C}\right)$ associated with the melting of the polyester yarns, the second $\left(353.11^{\circ} \mathrm{C}\right)$ associated 


\begin{tabular}{|c|c|c|c|c|c|c|c|c|c|}
\hline \multicolumn{10}{|c|}{ DSC RESULTS ANALYSES } \\
\hline Sample & \multicolumn{3}{|c|}{ Untreated material } & \multicolumn{2}{|c|}{ A } & \multicolumn{2}{|c|}{ CMC } & \multicolumn{2}{|c|}{ B } \\
\hline Weight (mg) & \multicolumn{3}{|c|}{3.4} & \multicolumn{2}{|c|}{3.7} & \multicolumn{2}{|c|}{2.8} & \multicolumn{2}{|c|}{2.5} \\
\hline Temp. max. $\left({ }^{\circ} \mathrm{C}\right)$ & 254.44 & 353.11 & 452.48 & 252.44 & 415.26 & 254.49 & 447.98 & 255.26 & 419.42 \\
\hline$\Delta \mathrm{H}(\mathrm{J} / \mathrm{g})$ & 26.95 & -77.97 & -210.54 & 22.73 & -16.47 & 31.93 & -638.79 & 12.39 & -3.75 \\
\hline Onset $\mathrm{t}\left({ }^{\circ} \mathrm{C}\right)$ & 253.30 & 340.86 & 435.32 & 249.38 & 407.16 & 252.38 & 418.27 & 252.32 & 415.57 \\
\hline
\end{tabular}

\begin{tabular}{|l|c|c|c|c|c|c|c|c|c|}
\hline \multicolumn{7}{|c|}{ DSC RESULTS ANALYSES } \\
\hline \multicolumn{1}{|c|}{ Sample } & \multicolumn{3}{|c|}{ PA } & \multicolumn{2}{c|}{ C } & \multicolumn{2}{c|}{ EZF } & \multicolumn{3}{c|}{ D } \\
\hline Weight $(\mathrm{mg})$ & \multicolumn{3}{|c|}{2.8} & \multicolumn{2}{c|}{2.4} & \multicolumn{2}{c|}{2.3} & - \\
\hline Temp. max. $\left({ }^{\circ} \mathrm{C}\right)$ & 254.45 & 427.13 & 253.77 & 422.27 & 255.26 & 432.67 & 252.77 & 420.33 & 419.42 \\
\hline$\Delta \mathrm{H}(\mathrm{J} / \mathrm{g})$ & 28.994 & -133.4490 & 9.5335 & 0.6313 & 24.8835 & -52.8754 & 19.3429 & -4.9547 & -3.75 \\
\hline Onset t $\left({ }^{\circ} \mathrm{C}\right)$ & 252.87 & 410.75 & 251.41 & 421.10 & 253.16 & 425.03 & 249.58 & 416.98 & 415.57 \\
\hline
\end{tabular}

with possible fiber impurities and the third endotherm $\left(452.48^{\circ} \mathrm{C}\right)$ associated with the burning of cotton [14]. Covering the materials with polymers and with $\mathrm{TiO}_{2}$ graphene, causes the enthalpy decrease of both fibers. It is possible that this decrease is due to the uneven deposition of the compounds, which leads to localized growth of thermal conductivity.

\section{Photocatalytic efficiency}

The aspect and the color modifications of the materials stained with methylene blue exposed 4 hours to visible light, are shown in the tables 5 and 6 .

As the notes on grey scale demonstrate, the doped $\mathrm{TiO}_{2}$-graphene induces a double degradation (table 6) of the methylene blue in comparison with untreated material and the materials treated with CMC, polyacrylic acid and cationic polymer. The highest lightness difference $\left(\mathrm{dL}^{*}\right)$ is recorded for sample a, coated with $\mathrm{TiO}_{2}$ /graphene. Instead, the highest color difference is recorded on the sample $D$, initially treated with the cationic polymer, followed in descending order by samples A, C and B. Probably, this effect is determined both by the uneven deposition of polymer layers and the blocking of a portion of $\mathrm{TiO}_{2}$ by the functional groups of the polymers (- carboxyl groups). The hypothesis is confirmed by the $\mathrm{dL}^{*}$ and $\mathrm{dE}^{*}$ values of samples treated only with polymers that decrease in the order: $\mathrm{PA}>\mathrm{CMC}>\mathrm{EZF}$.

ASPECT OF THE MATERIALS EXPOSED 4 HOURS AT VISIBLE LIGHT (XENOTEST)

\begin{tabular}{|c|c|c|c|c|}
\hline Time (hours) & Blank & CMC & Polyacrylic acid & EZF \\
\hline 0 & & & & \\
\hline 4 & & & & \\
\hline Time (hours) & A & B & C & D \\
\hline 0 & & & & \\
\hline 4 & & & & \\
\hline
\end{tabular}




\begin{tabular}{|c|c|c|c|c|c|c|c|c|c|}
\hline \multicolumn{10}{|c|}{$\begin{array}{c}\text { TRICHROMATIC COORDINATES OF THE MATERIALS STAINED WITH MB AND EXPOSED } 4 \text { HOURS } \\
\text { TO VISIBLE LIGHT }\end{array}$} \\
\hline Sample & $L^{*}$ & $a^{*}$ & $\mathbf{b}^{*}$ & $\mathrm{dL}^{*}$ & $d^{*}$ & $\mathrm{db}^{*}$ & $\mathrm{dE}^{*}$ & $\begin{array}{l}\text { Strength } \\
\text { SUM (\%) }\end{array}$ & Note \\
\hline Blank & 67.61 & -3.10 & -28.66 & 1.85 & 5.31 & 9.94 & 11.42 & 67.49 & 2.00 \\
\hline A & 77.74 & -3.10 & -11.37 & 8.86 & 10.32 & 12.62 & 18.55 & 47.67 & 1.00 \\
\hline CMC & 63.66 & -3.43 & -31.42 & 2.20 & 1.19 & 10.23 & 10.53 & 72.66 & 2.00 \\
\hline$B$ & 80.85 & -2.19 & -11.47 & 6.62 & 10.48 & 9.35 & 15.53 & 54.90 & 1.00 \\
\hline PA & 77.42 & -2.22 & -23.73 & 4.93 & 6.15 & 10.67 & 13.27 & 67.49 & 1.50 \\
\hline C & 79.52 & -1.59 & -10.14 & 6.62 & 10.44 & 10.56 & 16.26 & 55.72 & 1.00 \\
\hline$E Z F$ & 83.41 & -0.74 & -16.86 & 0.15 & 8.11 & 3.93 & 9.01 & 78.84 & 1.50 \\
\hline$D$ & 75.37 & -4.88 & -12.03 & 8.68 & 10.19 & 14.96 & 20.07 & 44.98 & 1.00 \\
\hline
\end{tabular}

Carboxymethyl cellulose (CMC) contains several carboxymethyl $\left(-\mathrm{CH}_{2}-\mathrm{COOH}\right)$ groups linked to the hydroxyl groups of the glucopyranosyl rings and interacts with a larger number of $\mathrm{TiO}_{2}$ molecules than polyacrylic acid, inhibiting the photocatalytic activity. Consequently, as the results show, the discoloration of methylene blue is more intense on the sample treated with polyacrylic acid and $\mathrm{TiO}_{2}$ /graphene (sample $\mathrm{C}, \mathrm{dE}^{*}=16.26$ ) than that on the sample treated with $\mathrm{CMC}$ and $\mathrm{TiO}_{2}$ /graphene (sample $\mathrm{B}$, $\left.\mathrm{dE}^{*}=15.53\right)$. This demonstrates that the discoloration is induced by the photocatalytic effect of $\mathrm{TiO}_{2}$ graphene and not by any possible absorption of the dye by the polymers although the CMC is amorphous and according to SEM images is deposited in thicker layers than the polyacrylic acid.

The photocatalytic properties of the samples on the degradation of methylene blue (MB), in visible $(\lambda>400$ $\mathrm{nm})$ spectral regions $(\sim 1 \mathrm{~mW}$; at the irradiance of $2.5 \mathrm{~W} / \mathrm{m}^{2}$ ) were also measured by a PCC-2 (ULVAC RIKO, Chigasaki, Kanagawa, Japan) photocatalytic checker. The absorbance (ABS) is a measure of the photocatalytic efficiency of sample, higher negative values indicating better activity. The ABS values of the samples are depicted in the figure 3 .

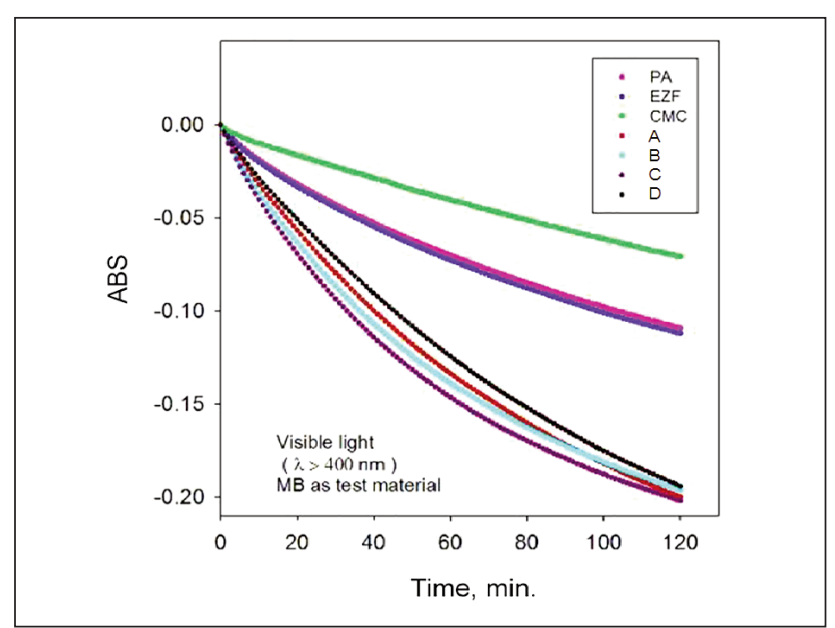

Fig. 3. The photocatalytic activity of the samples on the degradation of methylene blue
As the graph shows, the most intensive efficiency is demonstrated by the samples $\mathrm{c}$ and d (after 2 hours of exposure at visible light, almost $20 \%$ of dye is decomposed). No saturation tendency can be observed after 2 hours on irradiation in visible light. The slight differences between the two tests (UV-VIS spectrophotometry and photocatalytic checker) could be attributed to the intrisec non-uniformity of the textile materials and, accordingly to the deposited composites layers.

Evaluation of the photocatalytic effect after washing The treated materials were subjected to 5 washings at $40^{\circ} \mathrm{C}$ with distilled water. After drying, they were stained with $0.064 \mathrm{~g} / \mathrm{MB}$ for 20 minutes at $30^{\circ} \mathrm{C}$. The stained materials were exposed to visible light, the appearance and results of color change measurements being shown in tables 7 and 8 .

All the materials treated with $\mathrm{TiO}_{2}$-graphene preserve their photocatalytic efficiency after 5 washing cycles. According to the values of lightness and color differences, the highest photodegradation is shown by samples $C$ and $D$, pre-treated with polyacrilic acid and, respectively Itofix EZF and then with doped $\mathrm{TiO}_{2}$-graphene.

\section{CONCLUSIONS}

The SEM/EDAX analyses confirm the deposition of $\mathrm{TiO}_{2}$-graphene on fabrics. The fabrics coated with doped $\mathrm{TiO}_{2}$-graphene particles are highly hydrophilic due to the deposition of a high number of hydrophilic $\mathrm{TiO}_{2}$ particles on the materials surface. All the treated fabrics have electrical resistivity in the same range as untreated cotton/polyester.

The coated cotton/polyester fabrics with graphene oxide $/ \mathrm{TiO}_{2}$ nanocomposite show good photocatalytic self-cleaning activity evaluated by degradation of methylene blue under visible light irradiation. The used polymers promote greater adherence of the $\mathrm{TiO}_{2}$-graphene particles to the substrate demonstrated by the maintenance of the photocatalytic efficiency after 5 washing cycles. 
ASPECT OF THE MATERIALS EXPOSED 4 HOURS AT VISIBLE LIGHT (XENOTEST)ASPECT OF TREATED MATERIALS ACCORDING TO EXP. 8 AFTER 5 WASHES, EXPOSED 8 HOURS IN VISIBLE LIGHT

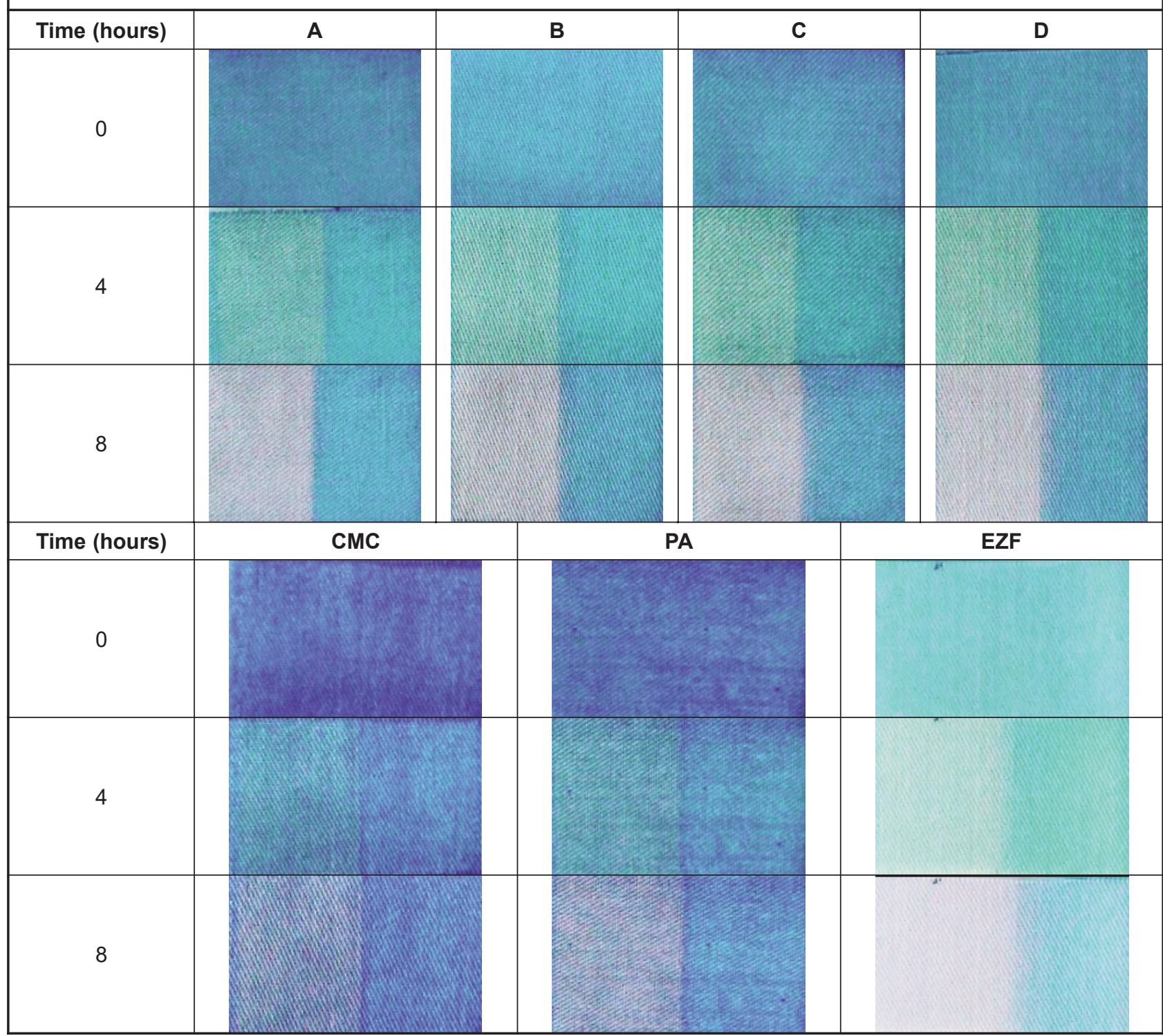

Table 8

TRICHROMATIC CO-ORDINATES OF THE MATERIALS AFTER 5 WASHES, EXPOSED 8 HOURS IN VISIBLE LIGHT (XENOTEST)

\begin{tabular}{|c|c|c|c|c|c|c|c|c|c|}
\hline Sample & $\mathbf{L}^{*}$ & $\mathbf{a}^{*}$ & $\mathbf{b}^{*}$ & $\mathbf{d L ^ { * }}$ & $\mathbf{d a *}$ & $\mathbf{d} \mathbf{b}^{*}$ & $\mathbf{d E}$ & $\begin{array}{l}\text { Strength } \\
\text { SUM (\%) }\end{array}$ & Note \\
\hline A & 74.92 & -1.07 & -10.60 & 9.36 & 12.01 & 20.98 & 25.92 & 44.35 & 1 \\
\hline CMC & 66.62 & -2.18 & -21.49 & 5.36 & 3.39 & 19.69 & 20.69 & 58.08 & 1 \\
\hline PA & 69.43 & -1.29 & -19.75 & 5.79 & 6.83 & 19.84 & 21.76 & 51.78 & 1 \\
\hline B & 75.89 & -0.73 & -9.75 & 10.44 & 11.82 & 20.92 & 26.20 & 46.13 & 1 \\
\hline C & 77.30 & -0.42 & -9.87 & 11.53 & 11.80 & 22.77 & 28.12 & 38.13 & 1 \\
\hline D & 77.96 & -0.50 & -9.13 & 11.50 & 12.21 & 21.37 & 27.17 & 38.19 & 1 \\
\hline EZF & 84.37 & 2.07 & -12.75 & 3.62 & 12.21 & 9.87 & 16.11 & 73.12 & 1 \\
\hline
\end{tabular}

\section{ACKNOWLEDGMENTS}

This work was supported by a research grant from The Executive Unit for Financing Higher Education, Research,
Development and Innovation (UEFISCDI) in the frame of Partnership PN II Program (Project No. 87/2014 - CLEANTEX). 


\section{REFERENCES}

[1] Gupta, D., Gulrajani, M.L., Self-cleaning finishes for textiles, available on-line, Available at: https://www.researchgate.net/publication/282482555_Self_cleaning_finishes_for_textiles [Accessed July 4th 2017]

[2] Vinu, R., Giridhar, M., Environmental remediation by photocatalysis, In: Journal of the Indian Institute of Science, 2010, 90, 2

[3] Norouzi, M., Maleknia, L., Photocatalytic Effects of Nanoparticles of TiO2 in Order to Design Self-Cleaning Textiles, In: Asian Journal of Chemistry, 2010, 22, 8, 5930-5936

[4] Wojtoniszak, M., Zielinska, B., Chen, X., et al., Synthesis and photocatalytic performance of $\mathrm{TiO}_{2}$ nanospheres-graphene nanocomposite under visible and UV light irradiation, In: J. Mater. Sci., 2012, 47, 3185-3190

[5] Zhang, H., Lv, X., Li, Y., et al., P25-graphene composite as a high performance photocatalyst, In: ACS Nano., 2009, 4, 380-386

[6] Nica, I.C., Stan, M.S., Popa, M., Chifiriuc, M.C., Lazar, V., Pircalabioru, G.G., Dumitrescu, I., Ignat, M., Feder, M., Tanase, L.C., Mercioniu, I., Diamandescu, L., Dinischiotu, A., Interaction of new-developed $\mathrm{TiO}_{2}$-based photocatalytic nanoparticles with pathogenic microorganisms and human dermal and pulmonary fibroblasts, In: Int. J. Mol. Sci., 2017, 18, 249

[7] Venkata, R.P., Viswadevarayalu, A., Janardhan R.K., Prathima B., Madhavi, V., Adinarayana R.S., Preparation of graphene- $\mathrm{TiO}_{2}$ nanocomposite and photocatalytic degradation of Rhodamine $B$ under solar light irradiation, In: Journal of Experimental Nanoscience, 2016, 11, 9, 722-736, https://doi.org/10.1080/17458080.2016.1144937

[8] Zgura, I., Frunza, S., Enculescu, M., Florica, C., Cotorobai, F., Deposition of titanium dioxide layers upon polyester textile materials: Checking the adherence by ultra-sonication, In: Rom. Journ. Phys., 2015, 60, 3-4, 488-494

[9] Yuranova, T., Laub, D., Kiwi, J., Synthesis, activity and characterization of textiles showing self-cleaning activity under daylight irradiation, In: Catal. Today, 2007, 122, 109-117

[10] Abidi, N., Cabrales, L., Hequet, E., Functionalization of a cotton fabric surface with titania nanosols: Applications for self-cleaning and UV-protection properties, In: ACS Appl. Mater. Interfaces 2009, 1, 2141-2146

[11] Kiwi, J., Pulgarin, C., Innovative self-cleaning and bactericide textiles, In: Catal. Today, 2010, 151, 2-7

[12] Hsieh, C.T., Chen, W., Water/oil repellency and work of adhesion of liquid droplets on graphene oxide and graphene surfaces, In: Surf Coatings Technol., 2011, 205, 4554-4561

[13] Deshmukha, H.P., Shinde, P.S., Patil, P.S., Structural, optical and electrical characterization of spray-deposited TiO2 thin films, In: Materials Science and Engineering, 2006, B, 130, 220-227

[14] Lin, L., et al., Preparation and properties of a washable flame-retardant coated fabric, In: Indian Journal of Fibre \&Textile Research, 2016, 41, 40-46

Authors:

IULIANA DUMITRESCU - In memoriam

OVIDIU-GEORGE IORDACHE1', CORNELIA-ELENA MITRAN',

ELENA PERDUM ${ }^{1}$, IRINA-MARIANA SĂNDULACHE' ${ }^{1}$,

LUCIA OANA SECĂREANU ${ }^{1}$, LAURENȚIU CHRISTIAN DINCA ${ }^{1}$, ARCADII SOBETKII ${ }^{2}$, LUCIAN DIAMANDESCU ${ }^{3}$

${ }^{1}$ National Research and Development Institute for Textile and Leather - INCDTP, 16 Lucretiu Patrascanu Street, 030508, Bucharest, Romania e-mail: office@incdtp.ro

${ }^{2}$ National Research-Development Institute for Non-Ferrous and Rare Metals - IMNR, 102 Biruintei Blvd., 077145, Pantelimon, Ilfov, Romania

${ }^{3}$ National Institute of Materials Physics - NIMP, 405 A, Atomistilor Street, Bucharest-Măgurele, Romania

Corresponding author:

OVIDIU-GEORGE IORDACHE

e-mail: ovidiu.iordache@incdtp.ro 